\title{
Indonesian Islamic Banking Consumer Behavior: What Do Not We Realize?
}

\author{
Dudi Permana, \\ Universitas Mercu Buana \\ dudi.permana@mercubuana.ac.id
}

DOI: $10.7176 / \mathrm{EJBM} / 11-29-03$

Publication date:October $31^{\text {st }} 2019$

\section{Introduction}

The Islamic financial system in Indonesia has been internationally assessed as one of the most complete Islamic financial system in the world. However, there are heavy challenges within the efforts of improving the Islamic finance in the country. One of these heavy challenges lies in the creation of customer base. In the same time, the creation of demand from the Islamic financial system should be given attention by all actors in the Islamic financial service sector, recalling the presence of increasing people with middle-class income background in the country that has been dominated by the Moslems (Edy, advisor of OJK in infobanknews.com, 2017).

Indonesia is one of the countries with the highest figure of Moslem people; in fact, most of the Indonesian people embrace Islamism as their religion. The implication is that from the existing religions in Indonesia Islam has been the dominant religion (www.bps.go.id).

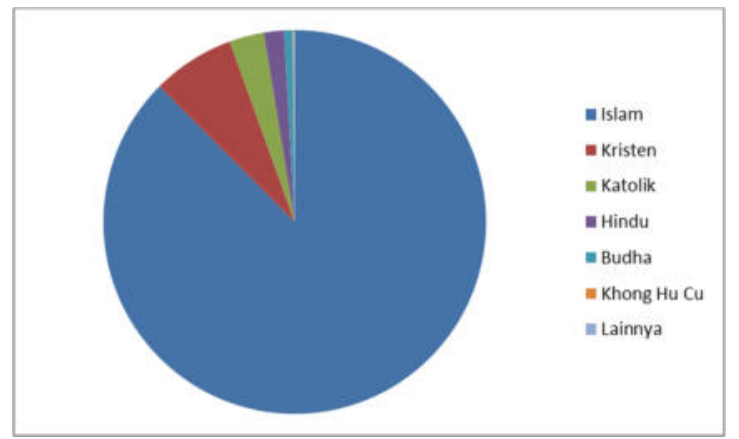

Source: Badan Pusat Statistik

Figure 1. Figure of Indonesian People based on the Adopted Religion

From Figure 1 above, it might be described that the total number of the disciples from each religion in Indonesia is as follows: $87.20 \%$ Indonesian people adopt Islamism, 6.96\% Indonesian people adopt Christianism, 2.91\% Indonesian people adopt Catholicism, 1.69\% Indonesian people adopt Hinduism, 0.72\% Indonesian people adopt Buddhism, 0.50\% Indonesian people adopt Confucianism and 0.13\% Indonesian people adopt other religions. In this regard, it might be concluded that most of the Indonesian people adopt Islamism.

The presence of Islamic banking institutions in the middle of Moslem people does not mean that these Islamic banking institutions have higher number of customers in comparison to the conventional banking institutions. On the contrary, the number of customers that the conventional banking institutions is higher than that of the Islamic banking institutions. 
Table 1. Comparison between the Islamic Banking Institutions and the Conventional Banking Institutions in terms of the Number of Customer

\begin{tabular}{lrrr}
\hline \multicolumn{1}{c}{ Year } & $\mathbf{2 0 1 4}$ & $\mathbf{2 0 1 5}$ & $\mathbf{2 0 1 6}$ \\
\hline Conventional Banks & $13,476,328$ & $13,867,941$ & $14,123,886$ \\
Islamic Banks & $2,684,382$ & $2,886,860$ & $3,309,058$ \\
\hline
\end{tabular}

Source: Statistical Data from Bank Indonesia

The results in Table 1 above show that the number of customers in the conventional banking institutions is higher than the number of customers in the Islamic banking institutions. In 2014 alone, the number of customers in the conventional banking institutions is $13,476,328$ while the number of customers in the Islamic banking institutions is 2,684,382. Moving to 2015, the number of customers in the conventional banking institutions is $13,867,941$ while the number of customers in the Islamic banking institutions is 2,886,860. Last but not the least, in 2016 the number of customers in the conventional banking institutions is 14,123,886 while the number of customers in the Islamic banking institutions is 3,309,058. Thereby, it might be concluded that until 2016 the number of customer that the Islamic banking institutions retain has not exceeded that of the conventional banking institutions.

In addition to having retained higher number of customers, the conventional banking institutions also enjoy more rapid development in comparison to the Islamic banking institutions. Not to mention, the number of conventional banking institutions shows higher rate of development in comparison to the number of Islamic banking institutions. The statement might be confirmed by the fact that the conventional banking institutions have occupied more office space in comparison to the Islamic banking institutions (http://www.ojk.go.id).

Table 2. The Development of Conventional Banking Institutions and Islamic Banking Institutions in terms of Number

\begin{tabular}{lrrr}
\hline \multicolumn{1}{c}{ Detail } & $\mathbf{2 0 1 3}$ & $\mathbf{2 0 1 4}$ & $\mathbf{2 0 1 5}$ \\
\hline Conventional Banks & & & \\
Number & 1,639 & 1,636 & 1,644 \\
$\begin{array}{l}\text { Islamic Banks } \\
\text { Number }\end{array}$ & 163 & 163 & 161 \\
\hline
\end{tabular}

Source: Statistik Perbankan Indonesia

From the results in Table 3, it is clear that the conventional banking institutions enjoy better development in comparison to the Islamic banking institutions. In 2013, the number of conventional banking institutions is 1,639 units while the number of Islamic banking institutions is 163 units. Then, in 2014 the number of conventional banking institutions is 1,636 units while the number of Islamic banking institutions is 163 units. Last but not the least, in 2015 the number of conventional banking institutions is 1,944 units while the number of Islamic banking institutions is 161 units. Looking at these comparisons, it might be further concluded that there has been a significantly huge gap between the conventional banking institutions and the Islamic banking institutions.

Departing from the above elaboration, it is certain that the number of conventional banking institutions have been increasing significantly while the number of Islamic banking institutions have been stable and even been decreasing. Therefore, the researcher would like to conduct a study that might encourage the public to benefit the service of Islamic banking institutions more since the public still heavily rely on the conventional banking 
institutions rather than the Islamic banking institutions. Then, in order to investigate the occurring phenomenon, within the study the researcher will implement the variable Religiosity and Brand Awareness as part of the hypothesis that has influence on Purchase Interest of Islamic banking institutions with Consumer Behaviour as the intervening variable.

\section{Literature Review}

In this section, the researcher would like to elaborate the theories that will serve as the backbone of the study. The theories that will be reviewed consist of Purchase Intention, Religiosity, Brand Awareness and Consumer Behaviour. Each theory will be elaborated briefly in the following sub-sections. In addition, the researcher will also provide the Hypotheses Development and the Research Framework that have been based on the theories that have been reviewed.

\subsection{Purchase Intention}

Sulistyari (2012:19) states that intention is defined as the possibility that a buyer has potentials to purchase a product. Then, she further states that purchase intention is the stage of the respondent's tendency to take action prior to the complete actualization of the intention to purchase a product. On the other hand, Schiffman \& Januk (2010) define that purchase intention is the model that an individual holds toward the goods that are completely appropriate in assessing the attitude toward the category of certain product, service or brand. Last but not the least, Kotler \& Keller (2014) define that purchase intention refers to the consumer behaviour that appears as a response toward the object that displays the desire of the consumer to perform a purchase. Based on these definition, it might be concluded that purchase intention is a model of attitude toward certain service, product or brandf that enables an individual to perform a purchase.

\subsection{Religiosity}

The term religiosity or religiousness is derived from a Latin word namely religisitas and the term was first coined in English on the $15^{\text {th }}$ Century. The preliminary understanding of the term religiosity was first used to define an expression of hyperbole or pathology for the sense of being religious (Karvos in Leeming, Madden \& Marlan, 2014). The term religiosity itself now implies an attitude of being religious and thus refers to the element of religion internalization within an individual (Glock \& Stark in Ancok, 2001). Departing from these definitions, it might be concluded that religiosity refers to the process of understanding and contemplating religion, religious knowledge and religious experience within the life of an individual.

\subsection{Brand Awareness}

According to Kartajaya (2010:64), brand awareness refers to the capacity of a potential consumer in either identifying or memorizing the brand due to the fact that the brand is part of certain product category. Similarly, Aaker in Handayani et al. (2010:62) defines that brand awareness refers to the capacity of a potential consumer in either identifying or recalling that brand belongs to certain product category.

\subsection{Consumer Behaviour}


Solomon (2000) defines that consumer behaviour or consumer attitude refers to a study that entails the process when an individual or a group of certain individuals purchase, utilize or arrange product, service, idea or experience in fulfilling their needs and desires. The term attitude itself refers to the mental or the neural aspect that has association with the responsiveness is organized through experience and has driving or dynamic influence toward behaviour (Setiadi, 2003).

\subsection{Theoretial Perspective and Hypothesis Development}

Departing from the theories that have been reviewed, in conducting the study there are three hypotheses that will be proposed and each hypothesis will be elaborated briefly as follows.

\subsubsection{Relationship between Religiosity and Consumer Behaviour}

Shouiden (2014) in his study has concluded that the more an individual is afraid of the punishment from the Lord the more he or she will develop an attitude that might benefit the Syarii' banks. Similarly, he has also concluded that the more an individual believes in the Islamic laws the more he or she will benefgit the Syariah banks. In the same time, the results of his study show that religious concern, belief or involvement has indirect influence on purchase intention. Therefore, it might be implied that religiosity has indirect influence on service purchase intention with the Syariah banks through the attitude of the consumer. On the other hand, Khan (2012) suggests that religiosity, awareness and service quality, religious support, social influence, cost effectiveness, competitive edge and availability have significant influence on the consumer attitude toward the Syariah banks. All of these factors play an important role in creating the consumer attitude toward the Syariah banking institutions; however, the findings in his stufdy show that religiousity has more contribution on the consumer attitude toward the Syariah banking institutions in comparison to the other variables. Departing from this elaboration, the researcher would like to propose the first hypothesis as follows:

\section{$H_{1}$ : Religiosity has positive and significant influence on Consumer Attitude}

\subsubsection{Relationship between Brand Awareness and Consumer Attitude}

Rehman (2010) shows that most of the consumers are not aware of multiple Syariah banking products such as Ijara funding and Murabaha funding. The implication of the statement is that the Syariah banking industry should provide more consideration toward the awareness of theur consumers. The Syariah banking institutions should hold certain seminars in order to inform the lines of product and service that the Syariah banking institutions offer. Departing from this elaboration, the researcher would like to propose the second hypothesis as follows:

$\mathrm{H}_{2}:$ Brand Awareness has positive and significant influence on Consumer Attitude.

\subsubsection{Relationship between Consumer Behaviour and Purchase Intention}

Lada et al. (2009) in their study show significant influence of the consumer attitude toward the utilization of Syariah banking products. Both the attitude and the interest to utilize the Syariah banking products are found to display positive relationship, which implies that the effort to change or to influence the potential consumers by means of educational campaign and marketing might cause both Moslem and non-Moslem people to choose the Syariah banking products.

$H_{3}:$ Consumer Attitude has positive and significant influence on Purchase Intention

\subsection{Conceptual Framework}


Based on both the theoretical review and the results of the previous studies, the researcher would like to design the conceptual framework for the conduct of the study as follows:

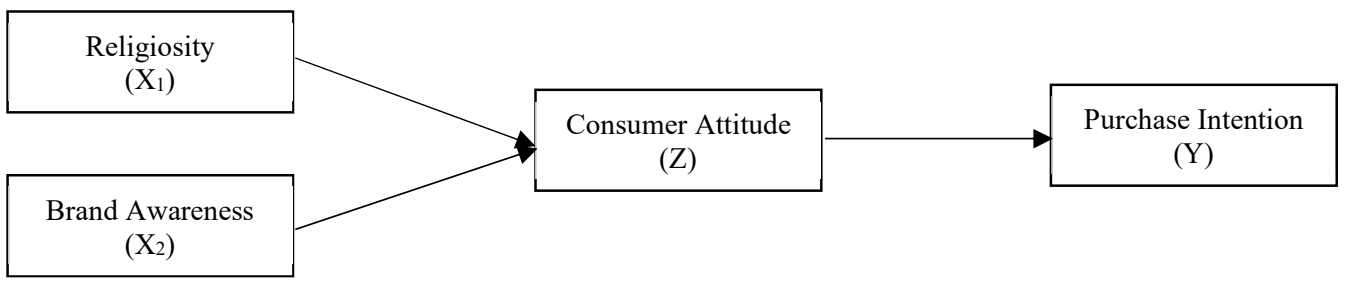

Figure 2. Conceptual Framework

\section{Methodology}

Prior to conducting the study, the method that had been used during the conduct of the study will be described in the following sections. Through the description, it is expected that the overall process within the conduct of the study might be well described.

\subsection{Population}

According Bougie et al. (2010) population is a generalization region consist of objects and subjects that have certain qualities and characteristics set by researchers to be studied and drawn the conclusions. Population can facilitate researchers in his research. In this study population is West Jakarta people who have never used Islamic bank. Due to the large population and researchers it is impossible to study everything in the population. So, it carried out the sampling of the population under study with Non-Probability Sampling technique used is Purposive sampling technique. According to Hair (2012), it states that the appropriate sample size in the SEM equation method is 100-200 samples, and depending on the number of parameters estimated, i.e. the number of samples 510 multiplied by the number of indicators. Based on the number of indicators $(5 \times 28=140)$ and $(10 \times 17=170)$. In this study researchers took 140 samples.

\subsection{Measurement Instrument}

The questionnaire was divided into four sections with each section separated by a specific heading. Instructions were clearly and precisely stated after each heading for ease of the respondents. The background of the respondent was presented in the final section of the questionnaire. This procedure was adopted following suggestions that sensitive questions were best set towards the end of the questionnaire.

\subsection{Religiosity}

Religiosity might be defined as an attitude of being religious, which implies the element $\mathrm{s}$ of religious internalization within an individual (Ancok, 2008). This instrument consists of ten items, about extent of respondents' perception about Islamic banking from the perspective of their religiosity. The items were obtained on a 5-point Likert-type scale.

\subsection{Brand Awareness}


Aaker in Handayani et al (2010), defines brand awareness is the ability of potential consumers to recognize or remember that a brand belongs to a particular product category. This instrument consists of four items, about the extent to which the ability of consumers to recognize the brand and distinguish it with other brands. The respondents' assessment of the effectiveness of brand awareness items were obtained on a 5-point Likert-type scale.

\subsection{Attitude}

Attitude, According to Ariani (2013) attitude is a form of reaction of one's feelings towards an object, whether feeling support or not supportive, impartial or impartial, likes or dislikes that cause a certain effect on one's behavior. This instrument consists of three items, related to what the consumer thinks before making a purchase of a product. The respondent assessments of the effectiveness of attitude items were obtained on a 5-point Likerttype scale.

\subsection{Intention}

According to Schiffman and Kanuk (2010), intention to behave is the frequency of purchase or the proportion of total purchases from buyers who are loyal to a particular brand. this instrument consists of four items, related to the buying interest of a consumer after knowing all the information about the product. The respondents' assessment of the effectiveness of attitude items were obtained on a 5-point Likert-type scale.

\section{Analysis}

A total of 85 responses were received at the end of the data collection process. profile of respondents can be analyzed in accordance with five aspects, namely gender, age, education level, occupation and amount of income. of 85 respondents, $51.8 \%$ of respondents were female and $48.2 \%$ male. the majority of respondents, 60 people aged between 21-25 years, as many as 16 respondents aged between 26-30 years, then the age range 31-35 years there are 6 respondents, and only 3 respondents are aged $>35$ years. almost the majority of respondents have last junior high school education as many as 58 people, while there are 2 respondents who did not finish junior high school. as many as 48 respondents are employees, the rest are followed by various other types of work. income of 49 respondents mostly ranges from Rp.3.500.000 - Rp.5.000.000.

\section{Results}

PLS (Partial Least Square) is a component analysis method or variance Based Structural Equation Modelling where in data processing is a program of Partial Least Square (Smart-PLS) version 3.0. PLS (Partial Least Square) is an alternative model of covariance-based SEM. PLS is intended for causal-predictive analysis in situations of high complexity and low theory support. (Ghozali, 2014).

\subsection{Measurement Model}

Within the conduct of the study, the researcher has implemented the convergent validity test and the discriminant validity test. The results of both tests might be consulted in the following sub-sections.

\subsubsection{Convergent Validity}


Test the convergent validity of each construct indicator. According to Chin in Ghozali (2014), an indicator is said to be a good valid if the value is greater than 0.70 while the loading factor of 0.50 to 0.60 can be considered sufficient. Based on these criteria, then when the loading factor is below 0.50 then the indicator must be removed from the model.

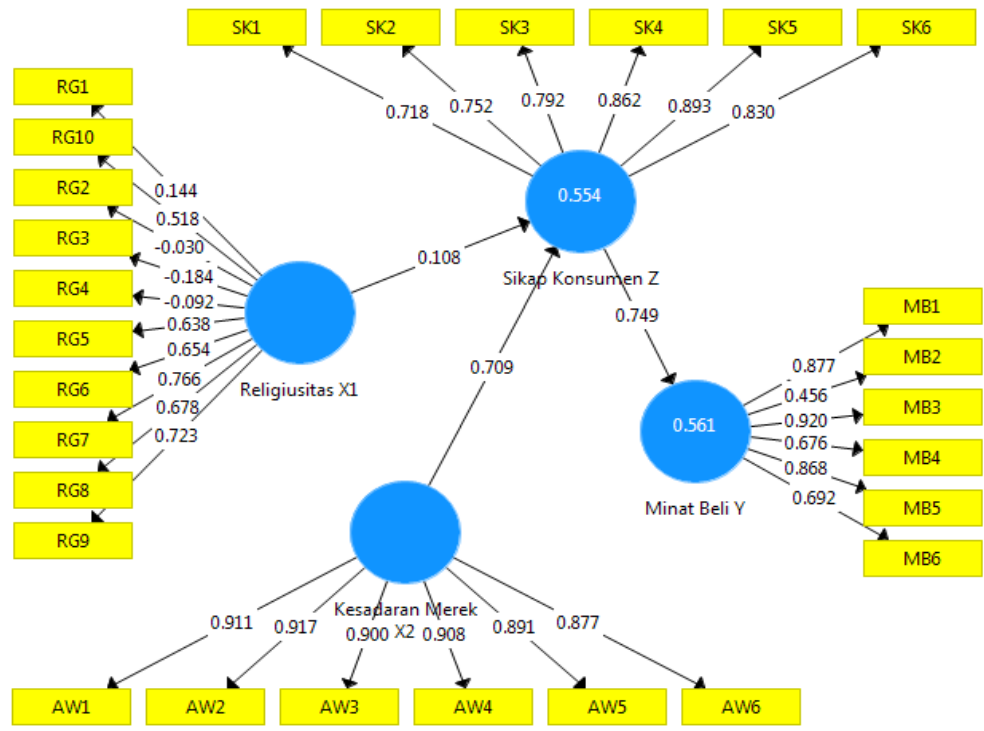

Figure 3. Evaluation Measurement Model (Designing Outer Model)

In convergent validity testing individual reflexive measure is said to be high if it correlates more than 0.70 with the construct that you want to measure. However, for the initial research phase, the development of measurement values of loading values 0.50 to 0.60 is considered sufficient (Chin, 1998 in Ghozali, 2014).

Loading factor below 0.7 should be deleted, then re-estimate. the amount of loading factor re-estimation results indicate that all indicators have good validity because it has a loading factor of more than 0.7. The AVE value indicates that all constructs have a potential reliability of greater than 0.5 . the next examination of convergent validity is reliability. the recommended AVE value should be greater than 0.5 (Ghozali, 2014).

\subsubsection{Discriminant Validity}

Discriminant validity can be done by cross loading examination that is if the construct correlation with the measurement item is greater than the size of the other construct.

Table 3. Factor Loadings and Reliability

\begin{tabular}{lcr}
\hline \multicolumn{1}{c}{ Items } & Composite R & \multicolumn{1}{c}{ AVE } \\
\hline Attitude & 0.894 & 0.656 \\
Brand Awareness & 0.953 & 0.811 \\
Intention & 0.891 & 0.821 \\
Religiosity & 0.855 & 0.629 \\
\hline
\end{tabular}

Table 4. Discriminant Validity Test (Fornell-Lacker) 


\begin{tabular}{lrrrr}
\hline & Awareness & $\begin{array}{c}\text { Purchase } \\
\text { Intentions }\end{array}$ & Religiosity & $\begin{array}{c}\text { Consumer } \\
\text { Behaviour }\end{array}$ \\
\hline Awareness & 0.901 & & & \\
Purchase Intention & 0.700 & 0.906 & & \\
Religiosity & 0.163 & 0.154 & 0.793 & 0.810 \\
Consumer Attitude & 0.737 & 0.759 & 0.201 & \\
\hline
\end{tabular}

Discriminant validity can be examined by comparing the squared correlations between the constructs and the variance extracted for constructs (Fornell and Larcker). As show in table 2, the squared correlation for each construct were less than the square root of the average variance extracted by the indicators measuring that constructs, indicating adequate discriminant validity. Thus, the measurement model demonstrated adequate convergent and discriminant validity.

\subsection{Structural Model}

Structural Model Structural Model or Hypothesis Test (Designing the inner model), namely the development of a model based on theoretical concepts in order to analyze the relationship between exogenous and endogenous variables that have been described in the conceptual framework. Estimated values for the relationship between pathways in the structural model must be significant. This significant value is obtained by a bootstrapping procedure. Looking at the significance of the hypothesis by looking at the parameter coefficients and the significant value of $\mathrm{t}$ statistics on the bootstrapping report algorithm, the significant value of $\mathrm{t}$ statistic must be $<1.96$.

Table 5. Summary of the Structural Model

\begin{tabular}{lrrr}
\hline Relations & Coefficient & t- value & Supported \\
\hline $\mathrm{H} 1 \mathrm{RG} \rightarrow \mathrm{CB}$ & 0.112 & 1.591 & $\mathrm{NO}$ \\
$\mathrm{H} 2 \mathrm{C} \rightarrow \mathrm{CB}$ & 0.000 & $17.891^{* * *}$ & YES \\
$\mathrm{H} 3 \mathrm{CB} \rightarrow \mathrm{PI}$ & 0.000 & $19.646^{* * *}$ & YES \\
\hline
\end{tabular}

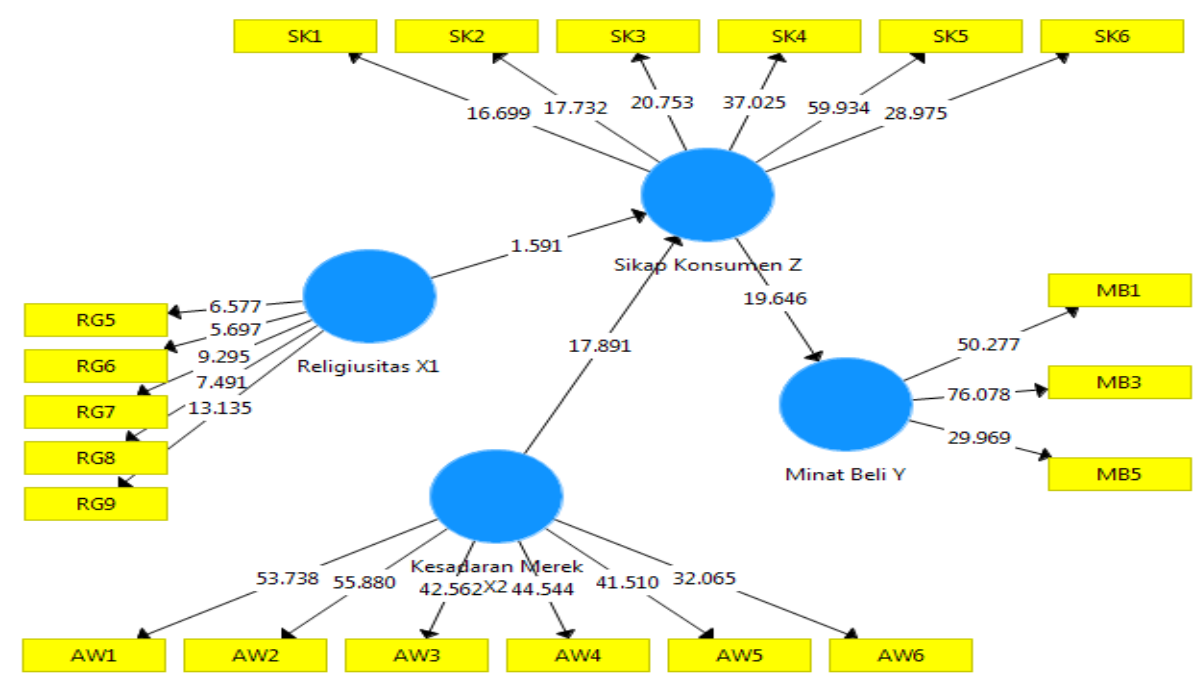

Figure 4. Structural Model

Based on table 3 above shows that brand awareness has a positive and significant effect on attitude, it can be seen from the t-count is 17.891 greater than $\mathrm{t}$ - table of 1.96 with error rate of $0.05(5 \%)$. While for the variable of 
religiosity have positive and not significant impact on attitude, it is indicated by $\mathrm{t}$-count value is 1.591 lower than t-table 1,96 with error rate $0,05(5 \%)$. Similarly, the attitude has a positive and significant impact on intention, this is indicated by a t-count value is 19.646 greater than $\mathrm{t}$ - table 1.96 with a error rate of 0.05 (5\%). Thus, it can be said that hypothesis $\mathrm{H} 2$ and $\mathrm{H} 3$ in this research accepted.

\section{Discussions and Implications}

Based on the results in Table 3, the calculation that has been performed shows that Religiosity does not have significant influence on Consumer Attitude. The reason is that the t-value is $1.591(<1.960)$. These results are not in accordance to the results of the study by Shouiden (2014), which show that Religiosity has indirect influence on Purchase Interest of Syariah banking service through the attitude toward these banks since the more an individual is afraid of the punishment from the Lord the more he or she will develop the attitude that might benefit the Syariah banks and the more an individual believes in the Islamic laws the more the attitude of the individual might benefit the Syariah banks.

In addition, the results of the study are not in accordance to the results of the study by Khan (2012), which show that Consumer Attitude toward Syariah banking institutions is influenced by quality service, religiosity, social impact, cost effectiveness, competitive edge and availability. All of these factors play an important role in creating the consumer behaviour toward the Syariah banking institutions; however, the findings from his study show that religious support has more contribution on the creation of consumer attitude toward the Syariah banking institutions in comparison to the other variables.

The reason is that the high level of religiosity has not been able to guarantee the perception and the emotion of the consumers that might be significant for the creation of consumer attitude on the Syariah banks. Such situation certainly impacts the purchase intention toward the Syariah banks through the mediation of the faith in God, the perception of God's supervision, the religion knowledge and the religion itself as the motivation in the behavioural conduct and alike. Another possibility might be that the respondents consider the use of service offered by the conventional banks as normal and thus the use of such service is not considered as part of usury. Therefore, the respondents are not concerned about committing any sin whenever they utilize the service offered by the conventional banks.

Based on the results in Table 3, it is found that Brand Awareness has positive and significant influence on Consumer Attitude. This finding is confirmed by the t-value that has been higher than the t-table $(17.891 * * * *>$ 1.960). These results are in accordance to the results of the study by Rehman (2010), which show that most of the customers are not aware of numerous Syariah banking products such as Ijara funding and Murabahah funding. The implication is that the Syariah banking industry should consider to make the customers aware of the Syariah banking products. The Syariah banking industry thus should hold certain type of seminars in order to inform the customer about numerous Syariah banking product and service.

In the same time, the results of the study are also in accordance to the results of the study by Khan (2012), which show that Consumer Attitude toward Syariah Banking Institutions is influenced by quality service, religiosity, social influence, cost effectiveness, competitive edge and availability. All of these factors play a significant role in creating the consumer behaviour toward the Syariah banking institutions. Despite this finding, within the study he has found that religiosity support has more contribution on the consumer attitude toward 
Syariah banking institutions in comparison to the other variables.

The high level of brand awareness might trigger the perception and the attitude of the consumer toward a product and also shape the purchase interest through the product that the consumer has been familiar with, the brand image, the brand impression of Syariah banks and alike. Through the brand awareness that involves knowledge, the consumer might be made familiar and convenient within the identification of Syariah banking and products and in turn the consumer will develop the purchase interest toward the Syariah banking products.

Last but not the least, the results of the study show that Consumer Attitude has significant influence on Purchase Intention. This finding is confirmed by the t-value that has been higher than the t-table $(19.466>1.960)$. Thus, the results of the study are in accordance to the results of the study by Lada et al. (2009), which show that Consumer Attitude has significant influence on the utilization of Syariah Banking Products. Attitude and interest to utilize the Syariah banking products are found to display positive relationship.

Furthermore, the results of the study are once again in accordance to the results of the study by Khan (2012), which show that Consumer Attitude toward Syariah Banking Institutions is influenced by quality service, religiosity, social influence, cost effectiveness, competitive edge and availability. All of these factors play a significant role in creating the consumer behaviour toward the Syariah banking institutions. Despite this finding, within the study he has found that religiosity support has more contribution on the consumer attitude toward Syariah banking institutions in comparison to the other variables. The reason is that the consumer attitude that has been based on the competitive edge of Syariah banking institutions and the favour toward the Syariah banking institutions will result in the belief that Syariah banking institutions have good quality and thus the consumer will have intention to save their money in the Syariah banking institutions. In fact, the consumer might even display their purchase intention toward the Syariah banking institutions.

\section{Limitations and Future Research}

Departing from the results of the study and the characteristics of the responses provided by the respondents, it is confirmed that Brand Awareness has significant influence on Customer Attitude that serves as the mediating variable for Purchase Intention. Furthermore, it is also confirmed that consumers are not aware of the products that have been offered by the Syariah banking institutions. Therefore, the Syariah banking institutions should improve the socialization activities or the introduction of the competitive products and services that Syariah banking institutions offer so that the purchase intention of the consumers might be improved as well.

Similarly, the results of the study and the characteristics of the responses provided by the respondents show that Consumer Attitude has significant influence on Purchase Intention of Syariah Banking Institutions. In the same time, it is found that the competitive edge of the Syariah banking institutions have not been realized by the consumers in comparison to that of the conventional banking institutions. Recalling that competitive edge is highly significant in forming the positive attitude among the customers, which in turn will result in the purchase intention, the awareness toward the competitive edge of the Syariah banking institutions among the consumers will be important to pursue in order that the consumer attitude toward the Syariah banking institutions might be improved. Consequently. The Syariah banking institutions should display their competitive edge in order to gain and retain the purchase intention among the consumers.

Despite the findings and the discussions, the study is not apart of limitations and one of these limitations is 
related to Religiosity. From the overall variables in the study, the researcher has found that the variable Religiosity does not have significant influence on Consumer Attitude as the mediating variable for Purchase Intention. Therefore, the future researchers are expected to include the variable Religiosity as the variable that might influence Purchase Influence and develop the study.

\section{REFERENCE}

Aaker, D. (2009). Managing Brand Equity. New York: John Willey \& Sons, Inc.

Ariani, R. (2011). Hubungan Antara Iklan Rokok Dengan Sikap dan Perilaku Merokok Pada Remaja. Semarang: Universitas Diponegoro.

Azwar, S. (2013). Metode penelitian. Yogyakarta: Pustaka Pelajar.

Bodibe, S., Chiliya, N., \& Chikandiwa. 2016. The Factors Affecting Customers' Decision to Adopt Islaic Banking. Volume II. Issue 4.

Ghozali, I. (2014). Metode Alternatif Dengan Partial Least Square, Edisi 4. Semarang: Universitas Diponegoro. Handayani, Desy, \& all. (2010). The Official MIM Academy Coursebook Brand Operation. Jakarta: Esensi Erlangga Group.

Jaffar, M. A., \& Musa, R. 2013. Determinants of Attitude towards Islamic Financing Among Halal-Certified Micro and SMEs : A Proposed Conceptual Framework. Vol.1 No 8.

Kotler, P., \& Keller, K. L. (2012). Marketing Management. Edisi 14. New Jersey: Prentice-Hall Published.

Kusuma, I. D., \& Untarini, N. 2014. Pengaruh Pengetahuan Produk Terhadap Niat Beli Dengan Sikap Sebagai Variabel Intervening. Vol 2 No 4.

Nitisusastro, M. (2012). Perilaku Konsumen Dalam Perspektif Kewirausahaan. Bandung: Alfabeta.

Peter, J., \& Olson, J. (2013). Perilaku Konsumen dan Strategi Pemasaran. Jakarta: Salemba Empat.

Rohmatun, A. H., \& Dewi, C. K. 2017. Pengaruh Pengetahuan Dan Religiusitas Terhadap. Ecodemica Journal, 27-35.

Sangadji, E. M., \& Sopiah. 2013. Perilaku Konsumen: Pendekatan Praktis disertai Himpunan Jurnal Penelitian. Yogyakarta: Andi Off Set.

Saptari, A. F., \& Sudiarti, T. 2013. Hubungan Sikap dan Pengetahuan Dengan Niat Mendukung Praktik Pemberian ASI Eksklusif Pada Mahasiswa Magister Pria Universitas Indonesia.

Schiffman, L. G., \& Kanuk, L. L. (2010). Perilaku Konsumen. Jakarta: PT. INDEK.

Sharaai, E. A. (2015). Understanding The Effect Of Environmental Studies In Lifestyle By Analyzing The Awareness, Knowledge And Attitudes Of Faculty Of Environmental Studies' Students In UPM Regarding The Consumption Of Eco Label Products. Australian Journal of Basic and Applied Sciences, 106-109. Sugiyono. 2013. Metode Penelitian Bisnis. CV. Alfabeta.

Suwarman, U. 2011. Perilaku Konsumen Teori dan Penerapannya Dalam Pemasaran. $2^{\text {nd }}$ Edition. Jakarta: PT. Ghalia Indonesia. 